\title{
Assessing Yield Responses of Four Improved Cassava Varieties in Akure, Nigeria
}

\author{
Odedina S. A., Ajayi A. J., Awoyemi S. O. \\ Department of Crop Production Technology, Federal College of Agriculture, Akure
}

\begin{abstract}
How to cite this paper: Odedina S. A., Ajayi A. J., Awoyemi S. O. (2020) Assessing Yield Responses of Four Improved Cassava Varieties in Akure, Nigeria. International Journal of Food Science and Agriculture, 4(1), 6-11.
\end{abstract}

DOI: $10.26855 /$ ijfsa.2020.03.002

*Corresponding author: Ajayi A. J., Department of Crop Production Technology, Federal College of Agriculture, Akure.

Email: ajayiaj@yahoo.com

\begin{abstract}
Experiments were conducted at the Federal College of Agriculture, Akure in 2015 and 2016 to evaluate yield response of four improved cassava (Manihot esculenta, Crantz) varieties. The experiment was set up in a $4 \times 2 \times 2$ factorial experiment comprising of four cassava (TME 419, TMS 98/0581, 98/0505 and 30572), two planting dates (May and June) and year of planting (2015 and 2016). Yield evaluation was done at 12 months after planting. Significant interaction was obtained between varieties and time of planting for the number of roots harvested per plot. TMS 0581 recorded the highest average number of cassava root harvested 144.8 tubers in 2016. The number of tuber rot obtained per plot was significantly influenced by cassava varieties. TMS 0505 had 24.1 tuber rot per plot in 2015 . This value amount to $13.2 \%$ loss in total number of storage roots formed and subsequent lowered yield $(25.21 \mathrm{t} /$ ha) compared with other varieties. Similarly, higher percentage of rotten roots (10.3\%) per plot was obtained for TMS 0505 in 2016. However, the root rot was only significantly lower than root yield of TMS 0581 that recorded 53.09 $\mathrm{t} / \mathrm{ha}$. The effect of time of planting was only significant for 2015 planting season. The four varieties evaluated exhibited high yield capacity under the production research plot.
\end{abstract}

\section{Keywords}

cassava yield, tuber rots, time of planting, cassava varieties

\section{Introduction}

Cassava (Manihot esculenta Crantz) is an important root crop in Nigeria. It serves as a staple for many households and recently is being promoted as an industrial crop. Nigeria is the largest producer of cassava in the world [1]. The country's actual production reported for 2017 by FAO was 59.5 million metric tons (MT) [2]. These reported data is the cumulative output of varying yield range from over 6, 792, 349 Hectares of land as reported. Wide yield gap, the difference between observed crop yields and those attainable in a given region [3] has been reported in cassava production in the country. Enabling farmers to narrow these gaps and stabilize yields in a sustainable manner is a major requirement for achieving long-term global food security. [4], reported that cultivation of low yielding varieties and ineffective extension systems has led to a wide gap between farmers' potential and actual yields. Apart from cultivation of low yielding varieties, the wide yield gap from farmers' field usually stem from lack of adequate agronomic practices such as cropping pattern, spacing, fertilizer application and weed management.

Cassava has earned the reputation of being well adapted to soils of low fertility. This stems from its ability to produce some yield in subsistence agricultural systems on soils of low fertility status and this has contributed greatly to its success over other staple food crops. [5] reported that cassava can grow and yield reasonably well on soil of low fertility where production of most other crops would be uneconomical. For this reason, peasant farmers do not fertilize cassava as they are contented with the minimal yield obtained from using limited inputs available to them. Farmers rarely use chemical fertilizer due to scarcity and cost. Farmers preferred improved cassava varieties because of their higher yields, early maturity, higher weed suppression, and greater resistance to diverse diseases and pests [6,7]. The current low yield of cassava makes Nigerian farmers uncompetitive in the cassava sector. This situation needs to be addressed 
through research on the use of improved cassava varieties with higher yield capacity. Improved cassava varieties have been reported to have higher yield potential. [8], affirms that new varieties are noted for their high tuber yield potential and resistance to pests and diseases. This necessitated the need to evaluate the performance of the improved cassava varieties under the existing soil fertility regime without fertilizer amendment mimics farmers' practice on the field but subject to other sound agronomic practices. The objectives of the study were to evaluate the effects of time of planting on performance of four improved cassava varieties.

\section{Materials and Methods}

Two years field experiments were conduced at the Federal College of Agriculture, Akure between May 2015 and June 2016 to evaluate the varietal response of four improved cassava varieties (Manihot esculenta, Crantz) under field demonstration plots. Akure is located in the humid region Southwest Nigeria with bi-modal rainfall pattern and annual rainfall range of $1200-1500 \mathrm{~mm}$.

The soil of each experimental plot was randomly samples for physico-chemical properties prior to planting. The result obtained is presented in table 1 .

\subsection{Experimental Designs}

The experiment was set up in a $4 \times 2 \times 2$ factorial experiment comprising of four cassava varieties (TME 419, TMS 98/0581, 98/0505 and 30572), two planting dates (May and June) and year of planting (2015 and 2016).

The experimental plot was laid out in a randomized complete block design with four replications. The experimental plot was ploughed, harrowed, ridged and divided into experimental units. Each experimental unit measured $18.75 \mathrm{~m} \times 25 \mathrm{~m}$. Planting was done at spacing of $1 \mathrm{~m} \times 0.8 \mathrm{~m}$.

\subsection{Field management}

Establishment of the field follow recommended good agronomic practices guide for the demonstration plot. Weed management was done through herbicide application. Pre-emergence herbicide, Primextra (Atrazine + Metalochlor) was applied at planting at rate of 6 litres /ha. Supplementary weeding was done at 8 weeks after planting.

\subsection{Yield evaluation}

Yield evaluation was done at 12 months after planting by harvesting a $5 \mathrm{~m}$ x $5 \mathrm{~m}$ quadrant from each plot. The yield parameters measured were number of stands and number of stems per plot, obtained by counting before harvesting. At harvesting, number of roots per plot, number of rotten roots and weight of tubers or roots per plot were estimated.

\subsection{Data Analysis}

The data collected were subjected to analysis of variance procedure using GENSTAT $12^{\text {th }}$ edition statistical analysis package and significant means were separated using least significant difference at 5\% probability level.

Table 1. Pre-cropping soil physical and chemical properties

\begin{tabular}{lll}
\hline Experiment & $\mathbf{2 0 1 5}$ & $\mathbf{2 0 1 6}$ \\
\hline Chemical properties & & \\
$\mathrm{pH}\left(\mathrm{H}_{2} \mathrm{O}\right)$ & 5.13 & 6.05 \\
Organic carbon $(\mathrm{g} / \mathrm{kg})$ & 8.60 & 15.40 \\
Organic matter $(\mathrm{g} / \mathrm{kg})$ & 14.80 & 26.60 \\
Nitrogen $(\mathrm{g} / \mathrm{kg})$ & 1.00 & 1.80 \\
Available Phosphorus $(\mathrm{mg} / \mathrm{kg})$ & 15.33 & 33.52 \\
Exchangeable $\mathrm{K}(\mathrm{cmol} / \mathrm{kg})$ & 0.12 & 0.31 \\
Exchangeable $\mathrm{Na}(\mathrm{cmol} / \mathrm{kg})$ & 0.10 & 0.36 \\
Exchangeable $\mathrm{Ca}(\mathrm{cmol} / \mathrm{kg})$ & 1.60 & 0.90 \\
Exchangeable $\mathrm{Mg}(\mathrm{cmol} / \mathrm{kg})$ & 1.20 & 0.60 \\
Physical properties & & \\
Sand $(\mathrm{g} / \mathrm{kg})$ & 560.0 & 520.0 \\
Silt $(\mathrm{g} / \mathrm{kg})$ & 300.0 & 330.0 \\
Clay $(\mathrm{g} / \mathrm{kg})$ & 140.0 & 150.0 \\
Textural class & Sandy clay loam & Sandy clay loam \\
\hline
\end{tabular}




\section{Results and Discussion}

The number of stems obtained per plot was not influenced by varieties in both years. However, the average effect of time of planting was significant with cassava planted in the month of May, recording higher number of stem per plot.

The average varietal effect was only significant in the second year (2016) of the experiment. The number of cassava stands per plot differs significantly in the trial planted in June 2015 with TMS 30572 recording significantly lower number of stands (16.5 stands per plot) at harvest. In 2016 however, TME 419 recorded the highest number of stands per plot.

The average effect of varieties on number of roots harvested per plot was significant with planting done in June 2016 with TMS 0581 recording the highest number (144.8) of cassava roots harvested per plot. Significantly higher number of tubers (206.3) per plot was harvested with planting done in May 2015. Significant interaction was obtained between varieties and time of planting for the number of roots harvested per plot. However, there were no significant Interaction between variety and time of planting with regards to number of roots harvested in the 2016 experiment. Also, there were no significant interaction between variety, time and year of planting.

The number of tuber rots obtained per plot was significantly influenced by cassava varieties. The average effect of varieties for cassava planted in 2015 showed that TMS 0505 and TME 419 had 24.1 and 17.8 tuber rots per plot. These values amount to $12.5 \%$ and $9.2 \%$ of total number of storage roots formed. In 2016, TMS 0505 also recorded higher number of rotten roots (11.63). Significant interaction between variety and time of planting was obtained in both years. Lower tuber rot in TMS 0581 and 30572 accounted for higher yield in both varieties in 2015. TMS 0505 and TME 419 yield were depressed due to high rot incidence. This was consistent with the report of [8] that tuber rot depressed the yield of cassava. Root rot has become a very important disease of cassava and was reported to cause about $20-80 \%$ yield loss [9].

The average weight of roots and the final yield obtained are related as the results obtained follow the same trend. Cassava yield ( $\mathrm{t} / \mathrm{ha}$ ) was influenced significantly by varieties. In 2015, TME 0505 recorded significantly lower yield (25.21 t/ha), while $35.16 \mathrm{t} /$ ha obtained from TMS 30572 was significantly different from TMS 0581 and TME 419. In 2016, TMS 0581 had significantly higher root yield of $53.09 \mathrm{t} / \mathrm{ha}$. The effect of time of planting was only significant in 2015. This was in agreement [8], who reported that time of planting influenced tuber yield of cassava. Also, interaction between variety, time and year of planting were significant.

Table 1. Effects of cassava varieties and time of planting on number of cassava stems and stands per plot at harvest.

\begin{tabular}{|c|c|c|c|c|c|c|}
\hline & \multicolumn{3}{|c|}{ Number of stems per plot } & \multicolumn{3}{|c|}{ Number of stands per plot } \\
\hline & May & June & Avg. Effect (variety) & May & June & Avg. Effect (variety) \\
\hline \multicolumn{7}{|l|}{2015} \\
\hline TMS 0581 & $53.20 \mathrm{a}$ & $39.2 \mathrm{a}$ & $46.2 \mathrm{a}$ & $23.75 a$ & $23.5 \mathrm{a}$ & $23.62 \mathrm{a}$ \\
\hline TME 419 & $54.20 \mathrm{a}$ & $36.8 \mathrm{a}$ & $45.5 \mathrm{a}$ & $23.75 a$ & $21.75 \mathrm{a}$ & $22.75 a$ \\
\hline TMS 0505 & $48.00 \mathrm{a}$ & $37.2 \mathrm{a}$ & $42.6 \mathrm{a}$ & $22.50 \mathrm{a}$ & $21.5 \mathrm{a}$ & $22.00 \mathrm{ab}$ \\
\hline TMS 30572 & $52.20 \mathrm{a}$ & $29.2 \mathrm{a}$ & $40.8 \mathrm{a}$ & $23.5 \mathrm{a}$ & $16.5 b$ & $20.00 \mathrm{~b}$ \\
\hline Avg. Effect (MOP) & 51.9 & 35.6 & & 23.38 & 20.81 & \\
\hline Variety & n.s & n.s & n.s & n.s & $\mathrm{S}$ & $\mathrm{S}$ \\
\hline MOP & & & S & & & $\mathrm{S}$ \\
\hline Var*MOP & & & n.s & & & $\mathrm{S}$ \\
\hline \multicolumn{7}{|l|}{2016} \\
\hline TMS 0581 & $34.85 \mathrm{ab}$ & $37.75 \mathrm{a}$ & $36.25 \mathrm{a}$ & $21.5 \mathrm{ab}$ & $20.50 \mathrm{a}$ & $21.00 \mathrm{a}$ \\
\hline TME 419 & $30.5 b$ & $24.25 \mathrm{bc}$ & $27.38 b$ & $23.75 \mathrm{a}$ & $17.50 \mathrm{a}$ & $20.62 \mathrm{a}$ \\
\hline TMS 0505 & $38.25 \mathrm{a}$ & $29.5 \mathrm{ab}$ & $33.88 \mathrm{a}$ & $20.00 \mathrm{~b}$ & $18.00 \mathrm{a}$ & $19.00 \mathrm{a}$ \\
\hline TMS 30572 & $28.5 b$ & $19.25 \mathrm{c}$ & $23.88 b$ & $17.75 b$ & $14.25 \mathrm{a}$ & $16.00 \mathrm{~b}$ \\
\hline
\end{tabular}


Table 1. cont.

\begin{tabular}{|c|c|c|c|c|c|c|}
\hline & \multicolumn{3}{|c|}{ Number of stems per plot } & \multicolumn{3}{|c|}{ Number of stands per plot } \\
\hline & May & June & Avg. Effect (variety) & May & June & Avg. Effect (variety) \\
\hline Avg. Effect (MOP) & 33.00 & 27.70 & & 20.75 & $\mathbf{1 7 . 5 6}$ & \\
\hline Variety & $\mathrm{S}$ & $\mathrm{s}$ & S & $\mathrm{s}$ & ns & S \\
\hline MOP & & & $\mathrm{s}$ & & & $\mathrm{s}$ \\
\hline Var*MOP & & & n.s & & & n.s \\
\hline Year & & & $\mathrm{s}$ & & & $\mathrm{s}$ \\
\hline Var*MOP*Year & & & n.s & & & n.s \\
\hline
\end{tabular}

Means with the same letter (s) within column and year are not significantly different at $5 \%$ probability level.

${ }^{+} \mathrm{MOP}$ - time of planting; ${ }^{++}$Var- variety

Table 2. Effects of cassava varieties and time of planting on number of cassava roots harvested and number of tuber rot per plot

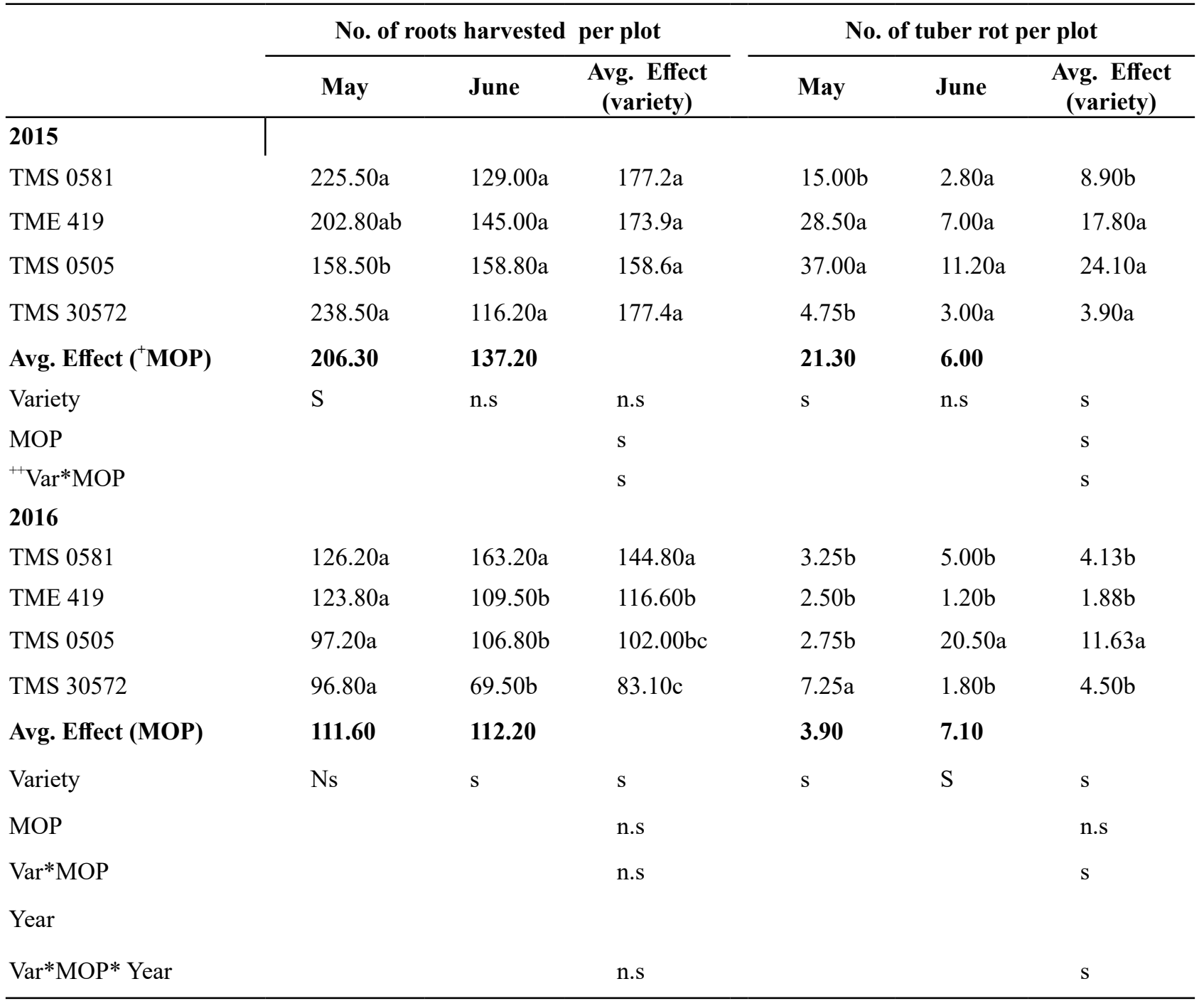

Means with the same letter (s) within column and year arenot significantly different at 5\% probability level.

${ }^{+}$MOP- time of planting; ${ }^{++}$Var- variety 
Table 3. Effects of cassava varieties and time of planting on cassava root yield

\begin{tabular}{|c|c|c|c|c|c|c|}
\hline & \multicolumn{3}{|c|}{ Weight of roots per plant (kg/plant) } & \multicolumn{3}{|c|}{ Yield (t/ha) } \\
\hline & May & June & $\begin{array}{c}\text { Avg. Effect } \\
\text { (variety) }\end{array}$ & May & June & $\begin{array}{c}\text { Avg. Effect } \\
\text { (variety) }\end{array}$ \\
\hline \multicolumn{7}{|l|}{2015} \\
\hline TMS 0581 & $3.22 \mathrm{a}$ & $2.18 \mathrm{a}$ & $2.70 \mathrm{a}$ & $40.29 \mathrm{a}$ & $27.20 \mathrm{a}$ & $33.74 a$ \\
\hline TME 419 & $2.57 \mathrm{ab}$ & $2.30 \mathrm{a}$ & $2.44 \mathrm{ab}$ & $32.16 \mathrm{ab}$ & $28.71 \mathrm{a}$ & $30.43 \mathrm{ab}$ \\
\hline TMS 0505 & $2.12 b$ & $1.91 \mathrm{a}$ & $2.02 b$ & $26.53 b$ & $23.90 \mathrm{a}$ & $25.21 b$ \\
\hline TMS 30572 & $3.13 \mathrm{a}$ & $2.50 \mathrm{a}$ & $2.81 \mathrm{a}$ & $39.07 \mathrm{a}$ & $31.25 \mathrm{a}$ & $35.16 \mathrm{a}$ \\
\hline Avg. Effect (MOP) & 2.76 & 2.22 & & 34.51 & 27.76 & \\
\hline Variety & $\mathrm{S}$ & n.s & s & $\mathrm{s}$ & n.s & $\mathrm{s}$ \\
\hline MOP & & & $\mathrm{s}$ & & & $\mathrm{s}$ \\
\hline Var* MOP & & & ns & & & ns \\
\hline \multicolumn{7}{|l|}{2016} \\
\hline TMS 0581 & $3.76 \mathrm{a}$ & $4.74 \mathrm{a}$ & $4.25 \mathrm{a}$ & $46.94 \mathrm{a}$ & $59.25 \mathrm{a}$ & $53.09 \mathrm{a}$ \\
\hline TME 419 & $2.35 \mathrm{a}$ & $2.48 \mathrm{~b}$ & $2.42 \mathrm{~b}$ & $29.35 \mathrm{a}$ & $31.02 \mathrm{~b}$ & $30.18 b$ \\
\hline TMS 0505 & $2.57 \mathrm{a}$ & $2.51 \mathrm{~b}$ & $2.54 \mathrm{~b}$ & $32.16 \mathrm{a}$ & $31.42 \mathrm{~b}$ & $31.79 b$ \\
\hline TMS 30572 & $2.74 \mathrm{a}$ & $2.49 \mathrm{~b}$ & $2.62 b$ & $34.30 \mathrm{a}$ & $31.12 b$ & $32.71 b$ \\
\hline Avg. Effect (MOP) & 2.85 & 3.06 & & 35.69 & 38.20 & \\
\hline Variety & n.s & $\mathrm{S}$ & $\mathrm{s}$ & n.s & $\mathrm{s}$ & $\mathrm{S}$ \\
\hline MOP & & & n.s & & & n.s \\
\hline Var*MOP & & & n.s & & & n.s \\
\hline Year & & & & & & $\mathrm{s}$ \\
\hline Var*MOP* Year & & & n.s & & & n.s \\
\hline
\end{tabular}

Means with the same letter (s) within column and year are not significantly different at 5\% probability level.

${ }^{+}$MOP- time of planting; ${ }^{++}$Var- variety

\section{Conclusion}

The month of planting played no significant role in influencing the cassava yield. Probably due to establishment in the early season when the crops have opportunity for good growth. The four varieties evaluated exhibited high yield capacity.

\section{Acknowledgement}

We acknowledge Bill and Melinda Gate Foundation funded Cassava Adding Value for Africa (C:AVA) Phase II Project and Federal College of Agriculture, Akure for support for the field work.

\section{References}

[1] Oketade E., Kulakow P., Parkes E.Y., Aina O.O and Akoroda M. O. (2018). Assessment of Root Dry Matter Content under Different Environments and Application of Fertilizer to Improved Cassava (Manihot esculenta 
Crantz) Genotypes in Two Agro-Ecologies in Nigeria. Book of Abstract. IVth International Cassava Conference, GCP 21, Benin, June11-15, 2018.

[2] FAOSTAT. 2019. Food and Agriculture Organization of the United Nations Statistics. www.fao.org/faostat/ en/\#data. Accessed February 25, 2019.

[3] International Center for Tropical Agriculture (CIAT) (2014). Reducing yield gaps for sustainable intensification of agriculture. CIAT Strategic initiative 2014-2020 bulletin.

[4] Okechukwu, R.U., Kehinde, I.A., Afolabi , C.G., James, B. and Egesi, C. (2011). Distribution of improved varieties of cassava and potential impact on root yield and disease reduction in Nigeria. African Journal of Root and Tuber Crops 9 (1): pp 58-63.

[5] Carter, S. E.; Fresco, L. O.; Jones, P. G. and Faribairn, J. N. (1992): An Atlas Cassava in Africa. Historical, agroecological and demographic aspects of crop distribution. Centre International de Agricultura Tropical, 85pp. cassava varieties inOyo State of Nigeria. Agric Syst. 24:305-317.

[6] Akoroda MO, Gebremeskel I, Oyinlola A. E. 1985. Impact of IITA cassava varieties in Oyo State of Nigeria. Ibadan: IITA; 105 p.

[7] Akoroda MO, Oyinlola A E, Gebremeskel T. 1987. Plantable stem supply system for IITA cassava varieties in Oyo State of Nigeria. Agricultural Systems. 24:305-317.

[8] Agbaje G. O. and Akinlosotu T. A (2004). Influence of NPK fertilizer on tuber yield of early and late-planted cassava in a forest alfisol of south-western Nigeria. African Journal of Biotechnology Vol. 3 (10), pp. 547-551. Available online at http://www.academic journals.org/AJB.

[9] Msikita W, Bissang B, James BD, Baimey H, Wilkinson HT, Ahounou M, Fagbemissi R. 2005. Prevalence and severity of Nattrassia mangiferae root and stem rot pathogen of cassava in Benin. Plant Diseases 89:12-16. 